\title{
USE OF FIVE Eucalyptus species FOR PARTICLEBOARDS MANUFACTURE1
}

\author{
Thiago Souza da Rosa ${ }^{2 *}$, Rosilani Trianoski ${ }^{3}$, Setsuo Iwakiri ${ }^{3}$ and Ghislaine Miranda Bonduelle ${ }^{3}$
}

\footnotetext{
${ }^{1}$ Received on 09.06.2016 accepted for publication on 14.03.2017.

${ }^{2}$ Universidade Federal do Paraná, Programa de Pós-graduação em Engenharia Florestal,Curitiba, Paraná - Brasil.. E-mail: $<$ thiagosouzadarosa@gmail.com>.

${ }^{3}$ Universidade Federal do Paraná, Departamento de Engenharia e Tecnologia Florestal,Curitiba, Paraná - Brasil. E-mail: $<$ rosillani@gmail.com>,<setsuo.ufpr@gmail.com>and <ghislainebonduellemiranda@gmail.com>.

*Corresponding author.
}

\begin{abstract}
The objective of this study was to evaluate the technical feasibility of the use of five Eucalyptus species, originating from plantations with short rotation cycle, for particleboards manufacture. The following species have been studied: Eucalyptus benthamii, Eucalyptus dunni, Eucalyptus grandis, Eucalyptus saligna, Eucalyptus urograndis, their mixture and Pinus taeda as a control. 21 wood particleboard have been produced, with nominal density of $0.65 \mathrm{~g} / \mathrm{cm}^{3}$, totaling 7 treatments. For the bonding, urea-formaldehyde resin was used, in the proportion of $8 \%$ of solids dry weight base of the particles, $2 \%$ of catalyst ammonium sulphate on weight of resin and $1 \%$ of paraffin. The Eucalyptus particleboards showed lower values of WA2h and WA24h than the particleboards produced with Pinus taeda. The particleboards composed Mix of species exhibited high dimensional stability similar to those produced with the pure Eucalyptus species. E. grandis showed values statistically higher of mechanical resistance (MOR and MOE) to those obtained by the other species studied, as well as, the Eucalyptus species were higher than the control species. In internal bond the particleboards produced with E. grandis was among the highest results of internal bond, being statistically similar to E. saligna. The species Mix particleboards exhibited proprieties in general similar to those produced with the pure Eucalyptus species. All species as well as the mix among them showed technical feasibility for particleboard manufacture.
\end{abstract}

Keywords: Short rotation; Fast growing species; Agglomerated particles panels.

\section{UTILIZAÇÃO DE CINCO ESPÉCIES DE EUCALYPTUS PARA A PRODUÇÃO DE PAINÉIS AGLOMERADOS}

\begin{abstract}
RESUMO - O objetivo deste estudo foi avaliar a viabilidade técnica da utilização de cinco espécies de Eucalyptus, provenientes de plantios com ciclo de curta rotação, para produção painéis aglomerados. Foram estudadas as espécies: Eucalyptus benthamii, Eucalyptus dunni, Eucalyptus grandis, Eucalyptus saligna, Eucalyptus urograndis, a mistura entre elas e o Pinus taeda como testemunha. Foram produzidos 21 painéis aglomerados, com massa específica nominal de $0,65 \mathrm{~g} / \mathrm{cm}^{3}$, totalizando em 7 tratamentos. Para a colagem utilizou-se a resina ureia-formaldeído, na proporção de $8 \%$ de sólidos base peso seco das partículas, $2 \%$ de catalisador sulfato de amônio sobre peso da resina e 1\% de parafina. Os painéis de Eucalyptus apresentaram menores valores de AA2h e AA24h do que os painéis produzidos com Pinus taeda. Os painéis compostos pelo Mix de espécies apresentaram estabilidade dimensional semelhante aos produzidos com as espécies de Eucalyptus puras. OE. grandis apresentou valores estatisticamente superiores de resistência mecânica (MOR e MOE) aos obtidos pelas demais espécies estudadas, assim como, as espécies de Eucalyptus foram superiores à espécie testemunha. $\mathrm{Na}$ tração perpendicular os painéis produzidos com $\boldsymbol{E}$. grandis apresentou entre os maiores resultados de tração perpendicular, sendo estatisticamente semelhante ao $\boldsymbol{E}$. saligna. Os painéis do Mix de espécies apresentaram propriedades em geral semelhantes aos produzidos com as espécies de Eucalyptus puras. Todas as espécies assim como a mistura entre elas mostraram viabilidade técnica para produção de painéis aglomerados.
\end{abstract}

Palavras-chave: Curta rotação; Espécies de rápido crescimento; Chapas de partículas aglomeradas. 


\section{INTRODUCTION}

According to the Indústria Brasileira de Árvores (2014), 66.4\% of the total consumption in natura of wood of the Brazilian industries of particleboard, are derived from the species of Pinus gender and only $31.7 \%$ of the genus Eucalyptus. However, the genus Eucalyptus has the largest area of planted forests in Brazil with approximately 5.56 million of hectares. According to ABRAF (2013), out of this total, 46.1\% is intended for the sector of coal and wood industry, $42.1 \%$ for pulp and paper and only $4.3 \%$ goes to the reconstituted panels sector.

The majority of these Eucalyptus woods due to being intended exclusively for the energy sector, are derived from short rotation forests, which are not used for other higher value added products such as sawn wood, by having insufficient diameter, or even presenting predominantly juvenile wood, resulting thus in a high coefficient of anisotropy and growth stress, impairing hence, the wood sawing, machining and drying.

On the other hand, problems arising from the juvenile wood that may interfere somehow in certain segments of the forest-based industry, are simply eliminated in the manufacture process of particulate panels, since the solid wood is reduced to wood chips, and subsequently the smaller particles. In addition, numerous studies performed such as Iwakiri et al. (2004), Iwakiri et al. (2008), Mendes et al. (2014), Cunha et al. (2014) and Gorski et al. (2015), prove that particleboards and OSB produced with Eucalyptus wood present, generally speaking, better physical and mechanical properties when compared to the panels traditionally manufactured with Pinus wood. Therefore, it is possible to produce panels of superior quality to those produced nowadays, and still, with the availability of obtaining raw materials from forests with more accelerated growth and cutting when compared to the Pinus forests.

Hence, such wood directed to energy generation can be converted into another high added value product, higher quality and with obtaining sources with the largest distribution in the country, in addition to increasing the wood diversity and volume of wood for industries operating in this branch, which has been growing increasingly in recent years.

Accordingly, considering the importance of targeting other species for the particleboard sector, this article aimed at evaluating the feasibility of using five Eucalyptus species, originating from short rotation cycles for the pure and mixed particleboards manufacture.

\section{MATERIALS AND METHODS}

\subsection{Raw material}

In this study, woods of Eucalyptus benthamii Maiden \& Cambage, Eucalyptus dunni Maiden, Eucalyptus grandis Hill ex Maiden, Eucalyptus saligna Smith and Eucalyptus urograndis (Eucalyptus urophylla $x$ E. grandis) from short rotation plantations aged 7 years, located in Rosário do Sul - RS. 5 trees per species were sampled, which were sectioned in logs, sawn and later processed for particles generation. As a control Pinus taeda L. was used from the region of Santa Cecília - SC, aged with 21 years old.

The species specific gravity was determined by the stereometric method following the recommendations of Copant 461/72 Standards. The wood chips were generated in a 4-knife rotating disc, and taken to an oven with forced air circulation to reduce the moisture. The dry chips were reprocessed in a hammer mill to obtain the "Slivers" particles. The particles were classified in an automatic classifier using sieves of 8 and 30 mesh with openings of $2.36 \mathrm{~mm}$ and $0.6 \mathrm{~mm}$, respectively. The 30-mesh sieve was used for the removal of fines (dust) and the 8-mesh sieve for the removal of "oversize" particles, and the particles obtained between these meshes, were intended for the panels manufacture. After classification, the particles were again subjected to drying to obtain a moisture content of approximately $3 \%$.

For the panels bonding urea-formaldehyde resin was used, with solids content of $66 \%$, and viscosity of $300 \mathrm{cP}$, in the proportion of $8 \%$ of solids based on the particles dry weight. It was also used $1 \%$ of paraffin to reduce the panels hygroscopic, and $2 \%$ of catalyst ammonium sulphate on weight of resin to accelerate the adhesive cure.

\subsection{Panels manufacture}

21 particleboards were manufactured, with dimensions of $50 \times 38 \times 1.2 \mathrm{~cm}$ and specific nominal density of $0.65 \mathrm{~g} / \mathrm{cm}^{3}$, being 3 panels for each of the 7 treatments. The panels were homogeneous way, i.e., the same size of particles was used throughout the panel. 
In addition to the use of species in their pure form, panels with a mixture of five species (Mix) of Eucalyptus were manufactured in a proportion of $20 \%$ each, and the control treatment (Pinus taeda).

The particles were taken to the rotary glue mixer and subjected to the application of urea-formaldehyde resin and emulsion of paraffin through air compressor spray pistol with meter container. After the bonding, the particles mattress was formed in a forming box and then the pre-pressing was performed manually for the air removal and the particles accommodation.

The mattress pressing was carried out in a hydraulic press with specific pressure of $40 \mathrm{kgf} / \mathrm{cm}^{2}$ and temperature of $160^{\circ} \mathrm{C}$ for a period of 10 minutes.

The panels manufactured were stored in a climate chamber with temperature of $20 \pm 2^{\circ} \mathrm{C}$ and relative humidity of $65 \pm 5 \%$, until they reached the moisture content of balance. After the panels stabilization, specimens were manufactured, which were taken again to the acclimatization for later achievement of physical and mechanics tests.

\subsection{Physical and mechanical tests}

All the physical and mechanical tests were performed following the European standards procedures: Apparent specific gravity (EN 323:2002), water absorption and thickness swelling (EN 317:2006), static bending (EN $310: 2006)$ and internal bond to the panel surface (EN 319:2006).

The results obtained in the tests were subjected to analysis of variance, and when the null hypothesis was rejected, the comparison of means of Tukey was carried out. All the analyses were carried out at the level of error probability of $5 \%$.

\section{RESULTS}

\subsection{Specific gravity and compression ratio}

The average results obtained for the specific gravity and compression ratio of the particleboards for each species are presented in Table 1.

The wood specific gravity ranged from 0.377 to 0.500 for P. taeda and E. dunnii, respectively. There were no statistically significant differences between the mean values of specific gravity of panels for all studied species. For compression ratio, there was no statistically significant differences between $P$. taeda, E. grandis and another species.

\subsection{Water absorption and thickness swelling}

The general average results obtained for the properties of water absorption and thickness swelling after 2 and 24 hours of the panels immersion are presented in Table 2 .

Statistically significant differences for water absorption after 2 and 24 hours among the species were found, being that $P$. taeda obtained the highest value for such properties. Only the panels produced with $E$. dunni and $E$. benthamii statistically differed among themselves, showing similarity to other species of the genus. For WA $24 \mathrm{~h}$ the panels composed of E. dunnii showed the highest mean value among the species of the genus, being the same statistically equal to E. urograndis. The Mix of species in all the properties of dimensional stability showed values similar to the pure Eucalyptus species.

For the thickness swelling after 2 hours, the panels manufactured with the species $E$. dunnii presented the lowest average value differing statistically from the other species. After 24 hours E. dunnii has also obtained the lowest swelling values, however, it did not differ statistically from the species $E$. benthamii, E. grandis and Mix.

The high dimensional instability that the Pinus taeda species provided for the panels was confirmed in TS $24 \mathrm{~h}$, with higher average value and differing statistically from the Eucalyptus species.

\subsection{Modulus of rupture, elasticity and internal bond.}

The average results obtained for the Modulus of Rupture (MOR), Modulus of Elasticity (MOE) and Internal Bond (IB) of panelboards built for each species, are presented in Table 3 .

For MOR and MOE, the panels composed by the species $E$. grandis, present values significantly higher for both properties. On the contrary, the control species P. taeda provided to the panels values statistically lower for the properties in question. The species $E$. benthami, E. dunnii, E. saligna, E. urograndis and Mix were statistically similar among themselves.

For the internal bond, the panels manufactured with $E$. grandis were statistically similar to E. saligna. The values obtained for the species E. urograndis,

Revista Árvore. 2017;41(2):e410215 
Table 1 - Average values of wood and panel specific gravity and compression ratio.

Tabela 1 - Valores médios de massa específica da madeira, do painel e razão de compactação..

\begin{tabular}{lccc}
\hline Species & $\mathrm{WSG}\left(\mathrm{g} / \mathrm{cm}^{3}\right)$ & $\mathrm{BSG}\left(\mathrm{g} / \mathrm{cm}^{3}\right)$ & Compression ratio \\
\hline E. benthamii & $0.497(13.26)$ & $0.635^{\mathrm{a}}(9.66)$ & $1.279^{\mathrm{c}}(9.66)$ \\
E. dunnii & $0.500(10.93)$ & $0.639^{\mathrm{a}}(9.80)$ & $1.276^{\mathrm{c}}(9.80)$ \\
E. grandis & $0.411(8.36)$ & $0.639^{\mathrm{a}}(9.22)$ & $1.555^{\mathrm{b}}(9.22)$ \\
E. saligna & $0.493(7.87)$ & $0.630^{\mathrm{a}}(10.05)$ & $1.278^{\mathrm{c}} \mathrm{c}(10.05)$ \\
E. urograndis & $0.472(7.35)$ & $0.634^{\mathrm{a}}(8.37)$ & $1.275^{\mathrm{c}}(8.37)$ \\
Mix* & $0.475-$ & $0.633^{\mathrm{a}}(9.86)$ & $1.333^{\mathrm{c}}(9.85)$ \\
P. taeda & $0.377(7.87)$ & $0.648^{\mathrm{a}}(9.14)$ & $1.719^{\mathrm{a}}(9.14)$ \\
\hline
\end{tabular}

$\mathrm{WSG}=$ Wood specific gravity; BSG = Board specific gravity; *Mix of 5 species of Eucalyptus;

Means followed by the same letter in the same column do not differ statistically among themselves by Tukey test at $5 \%$ probability; Values in parentheses refer to the coefficient of variation in percentage.

Table 2 - Average of water absorption and thickness swelling after 2 and 24 hours.

Tabela 2 - Valores médios de absorção d'água e inchamento em espessura após 2 e 24 horas..

\begin{tabular}{lcccr}
\hline Species & WA 2h (\%) & WA 24h (\%) & TS 2h (\%) & TS 24h (\%) \\
\hline E. benthamii & $9.83^{\mathrm{b}}(17.16)$ & $24.84^{\mathrm{ab}}(13.79)$ & $5.35^{\mathrm{b}}(14.40)$ & $10.744^{\mathrm{a}}(9.80)$ \\
E. dunnii & $8.65^{\mathrm{a}}(14.68)$ & $29.82^{\mathrm{d}}(14.43)$ & $4.72^{\mathrm{a}}(10.04)$ & $11.13^{\mathrm{ab}}(9.54)$ \\
E. grandis & $9.10^{\mathrm{ab}}(9.40)$ & $25.79^{\mathrm{bc}}(8.09)$ & $5.79^{\mathrm{bcd}}(14.22)$ & $11.05^{\mathrm{ab}}(11.20)$ \\
E. saligna & $9.33^{\mathrm{ab}}(12.58)$ & $22.28^{\mathrm{a}}(12.46)$ & $6.22^{\mathrm{d}}(11.08)$ & $11.76^{\mathrm{b}}(9.69)$ \\
E. urograndis & $9.65^{\mathrm{ab}}(14.40)$ & $28.00^{\mathrm{cd}}(12.43)$ & $5.99^{\mathrm{cd}}(11.99)$ & $11.76^{\mathrm{b}}(7.20)$ \\
Mix & $9.10^{\mathrm{ab}}(14.28)$ & $23.96^{\mathrm{ab}}(14.92)$ & $5.67^{\mathrm{bcd}}(13.41)$ & $10.37^{\mathrm{a}}(10.14)$ \\
$P$. taeda & $11.21^{\mathrm{c}}(12.80)$ & $37.02^{\mathrm{e}}(11.71)$ & $5.48^{\mathrm{bc}}(16.06)$ & $13.46^{\mathrm{c}}(10.36)$ \\
\hline
\end{tabular}

WA $2 \mathrm{~h}=$ water absorption after $2 \mathrm{hours;}$ WA $24 \mathrm{~h}=$ water absorption after 24 hours; TS $2 \mathrm{~h}=$ thickness swelling after $2 \mathrm{hours}$; TS $24 \mathrm{~h}=$ thickness swelling after 24 hours.

Averages followed by the same letter in the column do not differ statistically by Tukey test at $5 \%$ level of significance.

Values in parenthesis refer to the variation coefficient in percentage.

Table 3 - Average values of the panels mechanical properties.

Table 3 - Valores médios das propriedades mecânicas dos painéis..

\begin{tabular}{lccc}
\hline Species & MOR(MPa) & MOE (MPa) & IB (MPa) \\
\hline E. benthamii & $15.82^{\mathrm{b}}(21.28)$ & $2111.11^{\mathrm{b}}(17.93)$ & $0.78^{\mathrm{bc}}(20.50)$ \\
E. dunnii & $17.03^{\mathrm{b}}(21.20)$ & $2222.33^{\mathrm{b}}(18.31)$ & $0.74^{\mathrm{bcd}}(22.74)$ \\
E. grandis & $20.82^{\mathrm{a}}(20.42)$ & $2589.75^{\mathrm{a}}(17.92)$ & $0.91^{\mathrm{a}}(14.07)$ \\
E. saligna & $18.29^{\mathrm{b}}(21.95)$ & $2169.11^{\mathrm{b}}(21.51)$ & $0.79^{\mathrm{ab}}(21.51)$ \\
E. urograndis & $17.45^{\mathrm{b}}(20.40)$ & $2275.74^{\mathrm{b}}(16.43)$ & $0.64^{\mathrm{d}}(24.94)$ \\
Mix & $17.38^{\mathrm{b}}(20.11)$ & $2188.29^{\mathrm{b}}(20.00)$ & $0.66^{\mathrm{d}}(23.65)$ \\
$P$. taeda & $11.67^{\mathrm{c}}(20.18)$ & $1766.63^{\mathrm{c}}(16.99)$ & $0.67^{\mathrm{cd}}(14.35)$ \\
\hline
\end{tabular}

$\mathrm{MOR}=$ Modulus of rupture; $\mathrm{MOE}=$ Modulus of elasticity; $\mathrm{IB}=$ Internal bond;

Averages followed by the same letter in the column do not differ statistically by Tukey test at $5 \%$ level of significance.

Values in parenthesis refer to the variation coefficient in percentage.

E. dunnii, Mix and Pinus taeda were statistically similar among themselves presenting the lowest values for the property.

\section{DISCUSSION}

\subsection{Specific gravity and compression ratio}

As there was no statistical difference between the values of the panels specific gravity, it can be argued that the species did not influence this variable. However, it is worth mentioning that this variable is more associated with the control of the productive process, because the species have specific gravity very close to each other.

For compression ratio only the panels manufactured with E. grandis, Mix and P. taeda are within the range ideal proposed by Maloney (1993) from 1.3 to 1.6, which according to the author promotes good particles compression and, consequently, good physical and mechanical properties of the panels. 
The high value for compaction ratio obtained for P. taeda can negatively influence the dimensional stability properties. Iwakiri et al. (2008) report that a higher compression ratio of the panel obtained by the use of low density wood, increases the thickness swelling, harming the dimensional stability of the same. On the other hand, high compression ratio can positively influence the mechanical properties, resulting in panels with high values of resistance to static bending traction and surface internal bond.

In a general context, the species used had no influence on the specific panels gravity, however, the effect of differences among them was reflected in the compression ratio.

\subsection{Water absorption and thickness swelling}

The water absorption in both 2 and 24 hours was lower for the panels composed of Eucalyptus species when compared to the control Pinus taeda. E. dunnii exhibited the lowest value for WA2h and the largest for WA24h among the Eucalyptus species. The Mix of species in all the properties of dimensional stability showed values similar to the pure Eucalyptus species, being an indication that it is possible to choose from the mixture of species under the conditions of this study and obtain panels with good properties equally to those obtained with the pure species.

The reason for $P$. taeda result in panels with high dimensional instability, can be attributed to the low specific density of the species and consequent high compression ratio. According to Halligan (1970), high values of thickness swelling at high moisture contents, derives from the release of compression tension which occur during pressing, in a way that the specific wood density is of uttermost importance. In general, the species influenced the dimensional stability results, bearing in mind that the panels manufactured with Eucalyptus Spp. Produced more stable panels than those composed of P. taeda.

Observing the literature, it can be noted that the average values obtained for the properties of water absorption after 2 and 24 hours, the panels manufactured with the species E. benthamii, E. dunnii and E. grandis proved to be inferior to those obtained by Cunha et al. (2014), as well as the values of thickness swelling after 2 and 24 hours. For those produced with E. saligna, the values were also lower than those obtained by Guimarães et al. (2011) for the same properties. These differences may be related to the species' ages used by the authors, as well as the amount of resin, panels specific density and other parameters of the manufacture process.

The Standard EN 312:2003 does not stipulate minimum values of panels dimensional stability for use in dry conditions, however, all species complied with the minimum requirements recommended by the ABNT NBR14810-2 (2006) and ANSI A208.1 (2009), which set thickness swelling maximum of $8 \%$ for two hours and maximum of $40 \%$ after 24 hours of immersion, respectively.

It can be stated that the panels produced with the control (Pinus taeda) proved to be more unstable, i.e., they had a lower water resistance than the ones composed by Eucalyptus. Thus, choosing to use raw material from the Eucalyptus forests can be viable, generating a similar product under the same manufacture conditions and with superior quality, or even modify the process, in order to reduce the cost with volume of raw material.

\subsection{Modulus of rupture, elasticity and internal bond.}

The panels manufactured with E. grandis showed a high compression ratio when compared with the other species of the genus, which may be one of the reasons to generate panels with higher MOR and MOE values, however, the factors such as anatomical characteristics and structural species cannot be ruled out which may also have contributed to these results, since that, the Pinus taeda also obtained a high compression ratio, however, it showed the lowest values for the properties in question.

Cunha et al. (2014) obtained similar behavior for the properties of mechanical resistance, where the panels produced with E. grandis were also higher than those of other species of Eucalyptus and the mix among them balanced the results.

The highest resistance to internal bond obtained by the species E. grandis, can be explained due to the fact that the species has high compression ratio, along with its chemical by its high compression ratio, which in conjunction with the chemical plasticization proprieties. 
High values of compression ratios ensure a good contact between particles and good panel densification. Maloney (1993) states that the higher the compression between particles the greater the amount of resin used effectively among them, resulting in a good adhesion.

The high performance of E. grandis in this property was also observed by Cunha et al. (2014), which received the highest average value for the species. However, the authors also had high resistance values to traction for panels manufactured with the mixture of Benthamii, E. dunnii and E. grandis, which was not observed in this study for the mix among the five species. In this case, the proportion of the species E. saligna and E. urograndis present in the mix, may have influenced the traction resistance of the panels in this study.

In spite of Pinus taeda also exhibiting high values of compression ratio, the species did not stand out regarding such property. In this case, the wood chemical characteristics of the species may have hindered the bonding among particles, as well as the lower resin availability.

It was observed that the mixture of species did not favor the results of the property in question, therefore, presented an average value among the lowest ones obtained, and hence, it is possible to say that the mixture decreased the panela traction resistance when compared to those produced with E. benthamii, E. grandis and E. saligna, being that these together accounted for the largest percentage in the mixture.

It is possible to state that; the panels traction resistance is influenced by the species. This influence can be attributed to differences among the chemical characteristics involved in the adhesion process among particles.

All treatments composed of Eucalyptus species, met the requirements imposed by the Standard EN 312:2003 which establishes the minimum value of 13 MPa for MOR and $1800 \mathrm{MPa}$ for MOE. The panels produced with the control species did not comply with the minimum requirements demanded for this Standard.

When compared to Standard NBR14810-2 (2006), only the panels composed of the species E. grandis and E. saligna met the minimum requirement of $18 \mathrm{MPa}$ for MOR. The Standard aforementioned does not stipulate minimum values for the modulus of elasticity property.
Regarding the requirements demanded by the Standards EN 312:2003 and NBR14810-2 (2006), which set the minimum value of $0.40 \mathrm{MPa}$ for traction resistance, it is stated that all treatments are in accordance with the same.

\section{CONCLUSION}

Based on the results obtained in the study herein, it can be concluded that:

- The Eucalyptus species evaluated, originating from short rotation cycle, proved to be viable for the particleboards manufacture.

- The panels manufactured with the species of the genus Eucalyptus, exhibited properties in their majority higher than the panels manufactured with the control P. taeda.

- The panels manufactured with the species $E$. grandis showed greater mechanical resistance (MOR and MOE), when compared to the other treatments.

- The physical and mechanical properties of the panels are influenced by the species.

- The mixture of species was viable under the conditions of this study, obtaining satisfactory results and similar to those obtained by the pure Eucalyptus species.

\section{REFERENCES}

Associação Brasileira de Normas Técnicas \% ABNT. NBR 14810-2: Chapas de madeira aglomerada Parte 2: Requisitos. Rio de Janeiro: 2006.

Associação Brasileira de Produtores de Florestas Plantadas \% ABRAF. Anuário estatístico 2013, Ano base 2012. Brasília: 2013.

American National Standard Institute - ANSI A 208.1: Particleboard. Composite Panel Association. Leesburg: 2009.

Comissão Panamericana de Normas Técnicas COPANT 461: Determinación del peso especifico aparente. Buenos Aires: 1972.

Cunha AB, Longo BL, Rodrigues AA, Brehmer DR. Produção de painéis de madeira aglomerada de Eucalyptus benthamii, Eucalyptus dunnii e 
Eucalyptus grandis. Scientia Forestalis. 2014;42(102):259-67.

European Committee for Standardization. EN 310: Determination of modulus of elasticity in bending and of bending strength. Bruxelas: 2002 .

European Committee for Standardization - EN 317: Determination of swelling in thickness after immersion in water. Bruxelas: 2002.

European Committee for Standardization - EN 319: Determination of transverse tensile strength perpendicular to the plane of the board. Bruxelas: 2002.

European Committee for Standardization - EN 323: Wood based panels - Determination of density. Bruxelas: 2002.

European Committee for Standardization - EN 312: Particleboards - Specifications. Bruxelas: 2003.

Gorski L, Cunha AB, Rios PD, Trianoski R, Martarello LP. Produção de painéis de partículas orientadas (OSB) de Eucalyptus benthamii e Pinus spp. em diferentes combinações de camadas. Scientia Forestalis. 2015;43(106):367-75.

Guimarães Junior JB, Mendes LM, Mendes RF, Mori FA. Painéis de madeira aglomerada de resíduos da laminação de diferentes procedências de Eucalyptus grandis, Eucalyptus saligna e Eucalyptus cloeziana. Cerne. 2011;17(4):443-52.

Halligan A. F. A Review of Thickness Swelling in Particleboard. Wood Science and Technology,.1970;4:301-12.

Indústria Brasileira de Árvores - IBÁ. Anuário estatístico 2014: Indicadores do setor brasileiro de árvores plantadas. Brasília, DF: 2014. 100p.

Iwakiri S, Mendes LM, Saldanha LK, Santos JC. Utilização da madeira de eucalipto na produção de chapas de partículas orientadas OSB. Cerne. 2004;10(1):46-52.

Iwakiri S, Albuquerque CEC, Prata JG, Costa ACB Utilização de madeiras de Eucalyptus grandis e Eucalyptus dunnii para produção de painéis de partículas orientadas - OSB. Ciência Florestal. 2008;18(2):265-70.

Maloney TM. Modern particleboard \& Dryprocess fiberboard manufacturing. San Francisco: Miller Freeman; 1993. 689p.

Mendes RF, Mendes LM, Mendonça LM, Guimarães Júnior JB, Mori FA. Qualidade de painéis aglomerados homogêneos produzidos com a madeira de clones de Eucalyptus urophylla. Cerne. 2014;20(2):329-36. 